Mechanism of $\mathrm{O}$ and

C isotope

\title{
Mechanism of $\mathrm{O}$ and $\mathrm{C}$ isotope
} fractionation in magnesian calcite skeletons of Octocorallia corals and an implication on their calcification response to ocean acidification

T. Yoshimura ${ }^{1}$, A. Suzuki ${ }^{2}$, and N. Iwasaki ${ }^{3}$

${ }^{1} J a p a n$ Agency for Marine-Earth Science and Technology 2-15, Natsushima-cho, Yokosuka-city, Kanagawa 237-0061, Japan

${ }^{2}$ Geological Survey of Japan, National Institute of Advanced Industrial Science and Technology, Tsukuba Central 7, 1-1-1 Higashi, Tsukuba, Ibaraki 305-8567, Japan

${ }^{3}$ Faculty of Geo-Environmental Science, Rissho University, Magechi 1700, Kumagaya, Saitama 360-0194, Japan

Received: 27 November 2014 - Accepted: 1 December 2014 - Published: 8 January 2015 Correspondence to: T. Yoshimura (yoshimurat@jamstec.go.jp)

Published by Copernicus Publications on behalf of the European Geosciences Union.

fractionation in

magnesian calcite

skeletons

T. Yoshimura et al.

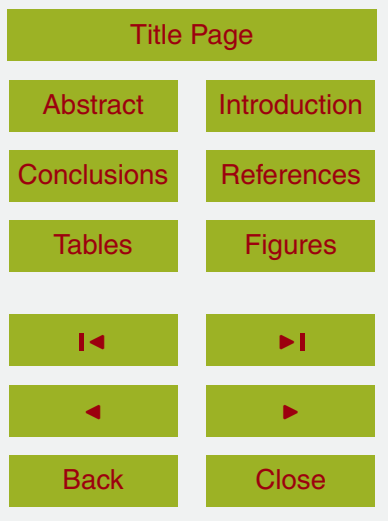

Full Screen / Esc

Printer-friendly Version

Interactive Discussion 


\section{Abstract}

Coral calcification is strongly dependent on both the $\mathrm{pH}$ and the dissolved inorganic carbon (DIC) of the calcifying fluid. Skeletal oxygen and carbon isotope fractionation of high-Mg calcite skeletons of Octocorallia corals directly record the biological manipula-

5 tion on sources of DIC in response to environmental changes. The coral skeletons were enriched in light isotopes $\left({ }^{16} \mathrm{O}\right.$ and $\left.{ }^{12} \mathrm{C}\right)$ relative to the expected values based on habitat environmental parameters and $\mathrm{Mg} / \mathrm{Ca}$ of the skeletons. The differences between the expected and observed values ranged from -4.66 to -1.53 for $\delta^{18} \mathrm{O}$ and from -7.34 to -1.75 for $\delta^{13} \mathrm{C}$. The large variability cannot be explained by the ambient environment, the contribution of metabolic carbon, or the precipitation rate of the skeleton. Therefore, the most plausible explanation for the observed $O$ and $C$ isotope differences in high-Mg calcite coral skeletons is the existence of two carbon sources, aqueous carbon dioxide in the calcifying fluid and dissolved inorganic carbon in seawater. Positive correlations of $\mathrm{B} / \mathrm{Ca}$ with $\delta^{18} \mathrm{O}$ and $\delta^{13} \mathrm{C}$ suggest that skeletal isotopic compositions 15 are enriched in light isotopes when conditions are less alkaline. Therefore, the relative contribution of isotopically heavy DIC from seawater through the skeleton and pericellular channels decreases under the reduced $\mathrm{pH}$ of the extracytoplasmic calcifying fluid. Our data suggest an even stronger biological effect under lower $\mathrm{pH}$. Skeletal $\delta^{18} \mathrm{O}$ and $\delta{ }^{13} \mathrm{C}$ values record the response of the sources of DIC in the coral calcifying fluids to ambient seawater $\mathrm{pH}$. These changes give insight into how ocean acidification impacts the physiological mechanisms as well as the $\mathrm{pH}$ offset between calcifying fluid and seawater in response to ocean acidification.

\section{Introduction}

Corals are a geologically important producer of biominerals that provide long-term records of environmental conditions over a wide range of water depths, from the surface to deep water. Octocorallia (Anthozoa) coral skeletons are composed of high-Mg
BGD

$12,389-412,2015$

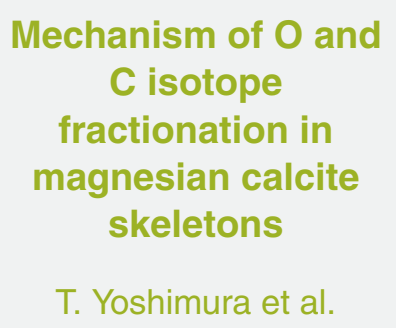

Title Page

Abstract Introduction

Conclusions

Tables

References

Figures

14

$>1$

4

-

Back

Close

Full Screen / Esc

Printer-friendly Version

Interactive Discussion 
calcite, and the longevity of these corals means that they can provide long-term records of environmental conditions in intermediate and deep waters (e.g., Smith et al., 1997; Adkins et al., 1998; Sherwood et al., 2005; Eltgroth et al., 2006; Montagna et al., 2006; van de Flierdt et al., 2006). Studies have reported significant isotopic disequilibrium 5 in calcitic coral skeletons (e.g., Heikoop et al., 2002; Noé et al., 2008), but a widely used approach, the "lines method" of Smith et al. (2000), can overcome strong vital effects and allow past changes in water temperature to be estimated (Hill et al., 2011; Kimball et al., 2014). Because skeletal $\delta^{18} \mathrm{O}$ and $\delta^{13} \mathrm{C}$ values are biased particularly by the inorganic carbon dynamics, which are affected by the coral calcification physi10 ology (Cohen and McConnaughey, 2003; Adkins et al., 2003; Rollin-Bard et al., 2003), the isotopic composition would give information to justify the physiological mechanisms controlling calcification.

Recently, intensely active research has been conducted on the sensitivity to the elevated $\mathrm{CO}_{2}$ and reduced seawater $\mathrm{pH}$ across various animal phyla such as mol15 lusks, crustaceans, and cold- and warm-water corals (e.g., Ries et al., 2009; IPCC, 2014). The decline in calcification rate has been suggested to be linked to a decline in $\mathrm{pH}$ in the calcifying fluid induced by ocean acidification (Ries, 2011a; Venn et al., 2013). The $\mathrm{pH}$ of the coral calcifying fluid is believed to be impacted by ocean acidification; moreover, coral regulates alkalinity pumping with a stronger biological $\mathrm{pH}$ up-regulation under condition of increased acidification (McCulloch et al., 2012a, b; Anagnostou et al., 2012; Venn et al., 2013). The dissolved inorganic carbon chemistry in intermediate water and deep water shows significant variations that depend on water depth and locality, and seawater $\mathrm{pH}$ levels are generally lower in deep waters (e.g., Key et al., 2004). Three polymorphs of $\mathrm{CaCO}_{3}$ have different solubilities in seawater make a greater impact on more soluble polymorphs such as aragonite and high-Mg calcite $(\mathrm{Mg} / \mathrm{Ca}>0.04)$. The sensitivity to ocean acidification across various animal phyla such as mollusks, crustaceans, and cold- and warm-water corals, has socioeconomic

BGD

12, 389-412, 2015
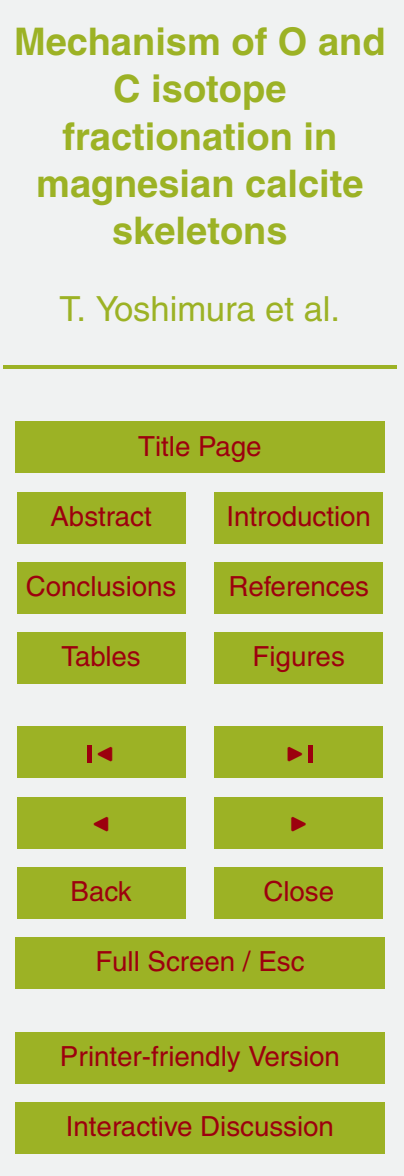
relevance (e.g., for coastal protection and fisheries). The number of species analyzed across studies has been determined for each category of elevated $\mathrm{CO}_{2}$.

Morever, the $\mathrm{CaCO}_{3}$ saturation state of coral calcifying fluids is strongly dependent on both $\mathrm{pH}$ and the dissolved inorganic carbon (DIC) concentrations. Currently, how5 ever, no direct measurements of DIC concentrations in coral calcification fluids are available. Skeletal oxygen and carbon isotope compositions directly record the biological manipulation on the sources of DIC in response to environmental changes. Therefore, Octocorallia corals represent a natural laboratory for the study of the response of coral calcification to $\mathrm{pH}$ changes because they are distributed at water depths rang10 ing from several dozen to thousands of meters. Moreover, this genus is not suitable for ocean acidification experimentation in a laboratory tank due to its slow cacification rate.

In this study, we investigated $\mathrm{O}$ and $\mathrm{C}$ isotope fractionation in the calcite skeletons of Octocorallia corals collected from sites at a range of water depths. Our aim was to 15 investigate the mechanisms responsible for skeletal $\delta^{18} \mathrm{O}$ and $\delta^{13} \mathrm{C}$ values.

\section{Materials and methods}

We selected 13 specimens of deep-sea coral (Paracorallium japonicum, Corallium elatius, C. konojoi, Corallium sp., and Keratoisis sp.) from several sampling localities at water depths of 30-1500 $\mathrm{m}$ in the western, northwestern, and northern Pacific (Table 1). Mean annual water temperatures at the sampling localities range from 2.5 to $19.5^{\circ} \mathrm{C}$ (water temperatures are from Levitus94; http://ingrid.Ideo.columbia.edu/ SOURCES/.LEVITUS94/) (Levitus and Boyer, 1994). The coral skeletons were ground to powder in an agate mortar before analysis. The $\mathrm{Mg} / \mathrm{Ca}$ ratios and the $\mathrm{Mg}$ isotope ratios of these specimens have already been reported by Yoshimura et al. (2011).

Oxygen and carbon isotope ratios were measured with an isotope ratio mass spectrometer (Micromass ISOPRIME) at the National Institute for Advanced Industrial Science and Technology. Isotopic data are reported as per mil (\%) deviations relative to
BGD

$12,389-412,2015$
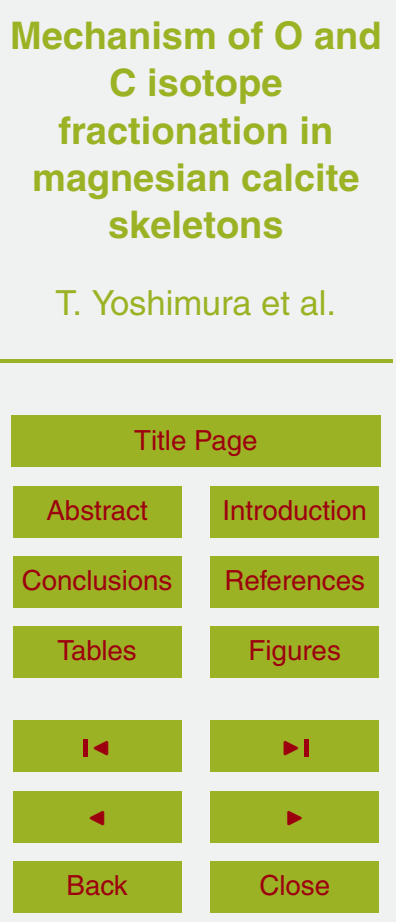

Full Screen / Esc

Printer-friendly Version

Interactive Discussion 
Vienna Peedee Belemnite (VPDB). The NBS-19 carbonate standard was used for calibration of the VPDB scale. Analytical precision was $\pm 0.1 \%$ for both $\delta^{18} \mathrm{O}$ and $\delta^{13} \mathrm{C}$.

For proxy evaluations, we used $\delta^{18} \mathrm{O}, \delta^{13} \mathrm{C}$, and $\left[\mathrm{CO}_{3}^{2-}\right]$ data from the inorganic carbon chemistry database, Global Ocean Data Analysis Project (GLODAP, http: 5 //cdiac.ornl.gov/oceans/glodap/; Key et al., 2004). The $\delta^{18} \mathrm{O}$ values used were $0 \%$ for most samples, and $+0.2 \%$ for DPC-V1 and DPC-V4. We selected $\delta^{13} \mathrm{C}$, alkalinity, and dissolved inorganic carbon (DIC) data that had been collected at points in the Pacific Ocean close to the deep-sea coral sampling localities, and we calculated other inorganic carbon data with the CO2SYS program (Lewis and Wallace, 1998). To cal10 culate fractionation and partitioning coefficients, we used values based on $\delta^{13} \mathrm{C}$-depth relationships determined near the coral sampling sites (Fig. 1).

\section{Results}

In the coral skeletons, $\delta^{18} \mathrm{O}$ varied from -2.38 to $-0.74 \%$, and $\delta^{13} \mathrm{C}$ varied from -6.12 to $0.00 \%$ (Table 1 ). We observed a large interspecimen variation in the relationship between these isotope ratios and temperature (Fig. 2a and b). The Mg content of calcite is known to substantially increase the isotope fractionation factor $\alpha$ at a given temperature (Tarutani et al., 1969; Jimenez-Lopez et al., 2004; Mavromatis et al., 2012). Therefore, to estimate the influence of $\mathrm{Mg}$ on isotope fractionation in the corals, we first calculated the difference values $\Delta^{18} \mathrm{O}\left(=\delta^{18} \mathrm{O}_{\text {coral }}-\delta^{18} \mathrm{O}_{\text {calc }}\right)$ and $\Delta{ }^{13} \mathrm{C}\left(=\delta^{13} \mathrm{C}_{\text {coral }}-\delta^{13} \mathrm{C}_{\text {calc }}\right)$, 20 where $\delta^{18} \mathrm{O}_{\text {coral }}$ and $\delta^{13} \mathrm{C}_{\text {coral }}$ are the observed isotopic compositions of the corals, and $\delta^{18} \mathrm{O}_{\text {calc }}$ and $\delta{ }^{13} \mathrm{C}_{\text {calc }}$ are those estimated by examining the effect of both temperature and $\mathrm{Mg}$ content on calcite-fluid isotope fractionation equilibria in synthetic magnesian calcite (Jimenez-Lopez et al., 2006; Mavromatis et al., 2012).

In the coral samples, the $\mathrm{Mg} / \mathrm{Ca}$ ratio ranged from 73.75 to $137.40 \mathrm{mmolmol}^{-1}$ and 25 showed a clear positive correlation with water temperature (Yoshimura et al., 2011). To evaluate the isotopic disequilibrium in high-Mg calcite skeletons of Octocorallia corals, we plotted $\Delta^{18} \mathrm{O}$ against $\Delta^{13} \mathrm{C}$ (Fig. 2c). Previous studies have examined the effect
BGD

12, 389-412, 2015

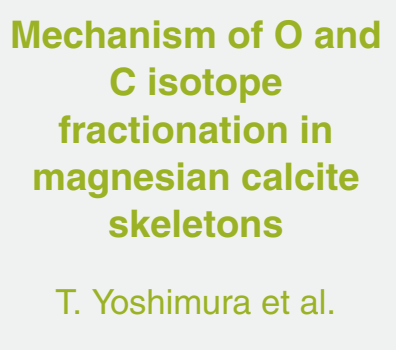

Title Page

Abstract Introduction

Conclusions

Tables

References

Figures

14

$>1$

$\triangleleft$

$\checkmark$

Back

Close

Full Screen / Esc

Printer-friendly Version

Interactive Discussion 
of $\mathrm{Mg}$ on oxygen isotope fractionation equilibria by theoretical calculations (Schauble et al., 2006; Chacko and Deines, 2008), but these theoretical models tend to underestimate the effect of $\mathrm{Mg}$ at lower temperatures and to overestimate its effect at higher temperatures, relative to data obtained empirically by experimental precipitation of magne5 sian calcite (Mavromatis et al., 2012).

Because Tarutani et al. (1969), Jimenez-Lopez et al. (2004), and Mavromatis et al. (2012) estimated different $\alpha$ values, we compared the relationships between magnesium content and $\delta^{18} \mathrm{O}$ at various temperatures between empirically determined fractionation factors (Mavromatis et al., 2012) and fractionation factors calculated ab 10 initio (Fig. 3) by Chacko and Deines (2008). The theoretical $\alpha$ values yielded positive $\Delta^{18} \mathrm{O}$ values when the resulting $\delta^{18} \mathrm{O}$ values were subtracted from those of the corals, indicating ${ }^{18} \mathrm{O}$ enrichment in the coral skeletons as high as $\sim 2 \%$ (Fig. 3). Theoretical $\alpha$ values determined by Schauble et al. (2006) yielded even more positive values. In contrast, the empirically obtained $\alpha$ values (Mavromatis et al., 2012) yielded negative $\Delta^{18} \mathrm{O}$ values for all samples (Fig. 3). The reason for this difference between empirical and theoretical $\alpha$ values is still uncertain, and its examination is beyond the scope of this study, but biogenic carbonates generally contain less ${ }^{18} \mathrm{O}$ and ${ }^{13} \mathrm{C}$ than inorganic calcite precipitated slowly from solution (e.g., Cohen and McConnaughey, 2003). If we estimate the effect of the Mg content by using the empirically determined oxygen and carbon isotope fractionation factors reported by Mavromatis et al. (2012) and JimenezLopez et al. (2006), the resulting $\Delta^{18} \mathrm{O}$ and $\Delta^{13} \mathrm{C}$ values range from -4.66 to -1.53 and from -7.34 to -1.75 , respectively (Table 1 ). These results indicate that both the oxygen and carbon isotope ratios of the calcitic corals in this study were depleted in heavier isotopes compared with the ratios of inorganic magnesian calcite.
BGD

$12,389-412,2015$
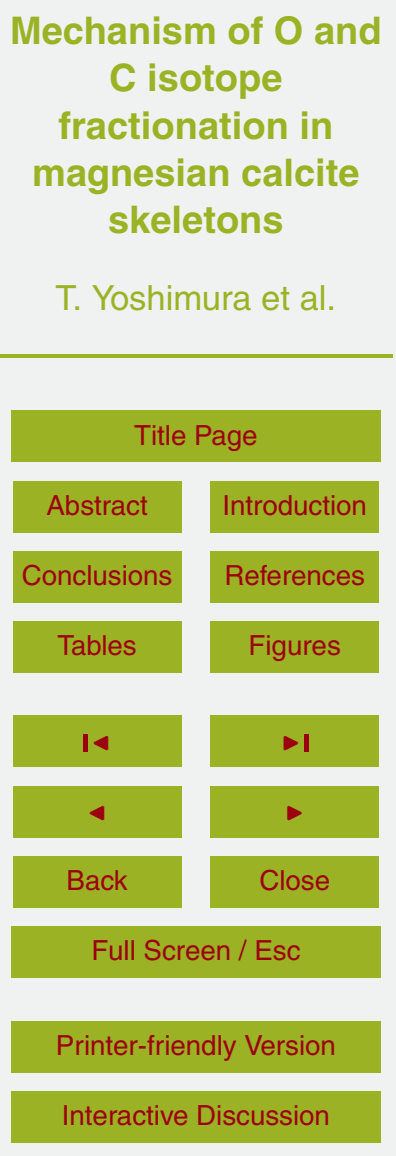


\section{Discussion}

\subsection{Factors controlling $\delta^{18} \mathrm{O}$ and $\delta^{13} \mathrm{C}$ values and $\mathrm{pH}$ effects}

The present study showed a significant variability of oxygen and carbon isotope fractionation, and the fractionation factors calculated for the corals exceeded the expected

5 values calculated from environmental signals, after taking into account their dependence on temperature and Mg contents (Jimenez-Lopez et al., 2006; Mavromatis et al., 2012). Moreover, simultaneous depletion of ${ }^{18} \mathrm{O}$ and ${ }^{13} \mathrm{C}$ in coral skeletons was observed relative to the calculated isotopic compositions for synthetic high-Mg calcite (Fig. 2c). The $\delta^{18} \mathrm{O}$ and $\delta^{13} \mathrm{C}$ values of scleractinian coral skeletons, which are composed of aragonite, are also several permil lower than those of inorganic aragonite precipitated slowly from solution (Cohen and McConnaughey, 2003). These biologically induced isotope fractionation effects differ from the physicochemically driven systematic effects observed in slowly precipitated inorganic carbonates.

McConnaughey (1989) examined isotopic disequilibrium in natural coral skeletons, and detailed assessments of the ${ }^{18} \mathrm{O}$ and ${ }^{13} \mathrm{C}$ depletion due to kinetic effects on fractionation have been investigated in corals cultured under controlled conditions (e.g., Suzuki et al., 2005; Omata et al., 2008). Such isotopic disequilibrium is due to incomplete equilibration during $\mathrm{CO}_{2}$ hydration/hydroxylation and the isotope exchange with ambient seawater during the rapid biologically mediated calcification. An effect of $20\left[\mathrm{CO}_{3}^{2-}\right]$ or $\mathrm{pH}$ on $\mathrm{O}$ and $\mathrm{C}$ isotope ratios has also been suggested (Spero et al., 1997; Zeebe et al., 1999a; Adkins et al., 2003). In this regard, pH may be more important than $\left[\mathrm{CO}_{3}^{2-}\right]$ because the relative abundance of DIC species is ultimately controlled by $\mathrm{pH}$, not $\left[\mathrm{CO}_{3}^{2-}\right]$ (Zeebe et al., 1999a; Uchikawa and Zeebe, 2010). Theoretical and experimental data indicate that $\delta^{18} \mathrm{O}$ and $\delta^{13} \mathrm{C}$ increase as $\mathrm{pH}$ decreases, because $25\left[\mathrm{HCO}_{3}^{-}\right] /\left[\mathrm{CO}_{3}^{2-}\right]$ increases and $\mathrm{HCO}_{3}^{-}$ions are more enriched in ${ }^{18} \mathrm{O}$ than $\mathrm{CO}_{3}^{2-}$ under isotopic equilibrium conditions, and, in the case of $\mathrm{d}^{13} \mathrm{C}$, because of effects of $\mathrm{pH}$ on kinetic isotope fractionation and the chemistry of the calcifying microenvironment (Zeebe
BGD

$12,389-412,2015$

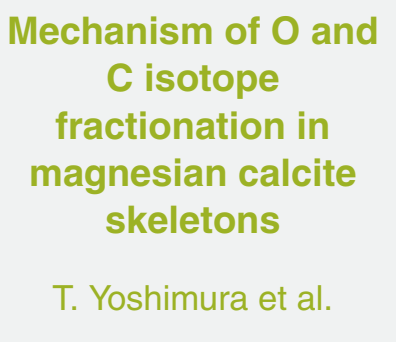

Title Page

Abstract Introduction

Conclusions

Tables

References

Figures

14

-1

4

-

Back

Close

Full Screen / Esc

Printer-friendly Version

Interactive Discussion 
et al., 1999a; Uchikawa and Zeebe, 2010). This relationship between stable isotope ratios and $\mathrm{pH}$ has been empirically verified only in foraminifera, but it has been observed in foraminifera regardless of the difference in physiology (Uchikawa and Zeebe, 2010). It is plausible, therefore, that the $\mathrm{pH}$ effect may control isotope fractionation in other calcitic organisms such as corals to some extent.

In addition, the relationship between the stable isotope ratios of carbon and oxygen is strongly linear in aragonitic corals (e.g., McConnaughey, 1989; Adkins et al., 2003). Moreover, intra-individual $\delta^{18} \mathrm{O}$ and $\delta^{13} \mathrm{C}$ values also show a linear relationship in corals with high-Mg calcite skeleton (Hill et al., 2011; Kimball et al., 2014). Empirical 10 calibration studies have shown that the intercept value of the regression equation for the coral $\delta^{18} \mathrm{O}-\delta^{13} \mathrm{C}$ relationship is a function of ambient water temperature. This finding is the basis of the "lines method" of calibrating paleothermometers for reconstructing past ocean temperatures in calcite producers (Hill et al., 2011; Kimball et al., 2014). Understanding of the possible fractionation mechanisms in the present coral samples 15 can improve both the proxy potential of coral records and also our understanding of coral biomineralization itself.

The carbon isotopic composition of biogenic carbonates is governed by both environmental and biological factors (McConnaughey et al., 1997). The ambient DIC concentration is generally regarded as the only source of carbon in coral skeletal carbonate, but if respired carbon contributes to the coral skeleton, its carbon isotopic composition is reduced (Griffin and Druffel, 1989; Adkins et al., 2003). Adkins et al. (2003) analyzed 12 modern calcitic corals from seven different genera, and they found the maximum contribution of respired carbon, estimated from $\Delta^{14} \mathrm{C}$, to be $8 \%$ in the specimen showing the maximum decline in $\mathrm{d}^{13} \mathrm{C}$ of $\sim 1 \%$. In this study, $\Delta^{13} \mathrm{C}$ values of the calcitic corals varied from -1.75 to $-7.34 \%$ o (Table 1 ), but these substantial offsets from inorganic carbon isotope fractionation during coral calcification were accompanied by large ${ }^{18} \mathrm{O}$ depletion. Therefore, we inferred that the contribution of respired carbon in these species was relatively minor compared to the large changes in skeletal $\delta^{13} \mathrm{C}$. Therefore, the large interspecimen variability of $\delta^{18} \mathrm{O}$ and $\delta^{13} \mathrm{C}$ observed in this study
BGD

$12,389-412,2015$

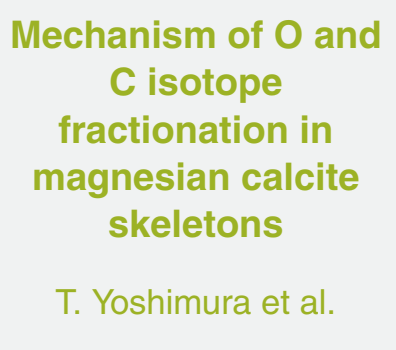

Title Page

Abstract

Introduction

Conclusions

Tables

References

Figures

14

$>1$

$\triangleleft$

$\checkmark$

Back

Close

Full Screen / Esc

Printer-friendly Version

Interactive Discussion 
suggests that in calcitic corals changes in the DIC carbonate system dominantly controls isotope fractionation.

In corals living at intermediate and deep depths, differences in the availability of nutrients at habitat water depths also affect coral calcification rates. The relationship be5 tween water depth and previously reported skeletal growth rates of calcitic Octocorallia coral taxa (Griffin and Druffel, 1989; Druffel et al., 1990; Garrabou and Harmelin, 2002; Marschal et al., 2004; Andrews et al., 2005; Bramanti et al., 2005; Roark et al., 2006; Bruckner and Roberts, 2009; Gallmetzer et al., 2010; Nguyen et al., 2013; Vielzeuf et al., 2013) indicates a growth rate decrease per meter of depth. Despite the large 10 habitat depth range represented by these corals, however, the variations in the isotope ratios were greater at some depths than they were between the surface and the deepest depths. The supposed relationship between water depth and higher $\mathrm{pH}$ or $\mathrm{CaCO}_{3}$ saturation state of the extracytoplasmic calcifying fluid (ECF), calcification would be enhanced and growth rates would be higher, but the variation in local habitat charac15 teristics and individual corals can account for the large variation in growth rates and $\delta^{18} \mathrm{O}$ and $\delta^{13} \mathrm{C}$ at certain depths.

\subsection{Coral calcification and mechanisms of isotope disequilibrium}

Because the magnitudes of $\delta^{18} \mathrm{O}$ and $\delta^{13} \mathrm{C}$ changes exceed the magnitude of ambient environment changes and because coral internal processes probably control the 20 isotopic composition of the coral skeleton, the key to understanding skeletal $\delta^{18} \mathrm{O}$ and $\delta{ }^{13} \mathrm{C}$ values is information about the coral ECF. In particular, how does the inorganic carbon chemistry of the ECF differ among individuals? The $\mathrm{pH}$-sensitive tracers such as boron isotopes and B/Ca (Foster et al., 2008; Allen and Hönisch, 2012) have been used to study past ocean $\mathrm{pH}$. Boron-based $\mathrm{pH}$ proxies rely on the fact that the rela25 tive abundances and $\mathrm{B}$ isotopic compositions of the two aqueous species of boron in seawater, $\mathrm{B}(\mathrm{OH})_{3}$ and $\mathrm{B}(\mathrm{OH})_{4}^{2-}$, are $\mathrm{pH}$ dependent (e.g., Kakihana et al., 1977; Sanyal et al., 2000). Compared with aragonitic corals, the calcitic coral Corallium sp. specimen has a significantly low $\delta^{11} \mathrm{~B}$, corresponding to a theoretical $\mathrm{pH}$ of $\sim 0.3$, suggest-
BGD

$12,389-412,2015$
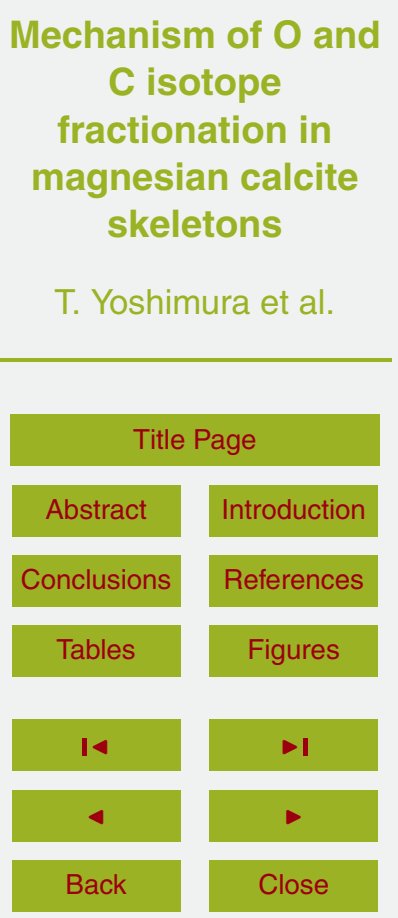

Full Screen / Esc

Printer-friendly Version

Interactive Discussion 
ing that the ability of this calcitic coral species to up-regulate the $\mathrm{pH}$ of the calcifying fluid is much less (McCulloch et al., 2012a). The B/Ca and U/Ca data of the specimens (Yoshimura et al., 2015) were used to evaluate the influence of ECF chemistry on isotopic compositions.

The high $\mathrm{B} / \mathrm{Ca}$ variability at a certain habitat depths was observed in the present coral samples (Yoshimura et al., 2015). Among the parameters studied, $\delta^{13} \mathrm{C}$ showed the highest correlation with $\mathrm{B} / \mathrm{Ca}$ (Table 2), and $\delta^{18} \mathrm{O}$ also showed a moderate positive correlation with boron (Fig. 4). These findings imply that ECF conditions influenced both $\mathrm{O}$ and $\mathrm{C}$ isotopic compositions simultaneously via variations in the relative proportions of dissolved carbon species in the coral calcifying fluid and/or the biologically induced isotopic disequilibrium processes rather than of seawater chemistry and temperature effects. If $\mathrm{B} / \mathrm{Ca}$ is assumed to be a function of the $\mathrm{pH}$ of the $\mathrm{ECF}$, and if the $\mathrm{B} / \mathrm{Ca}$ in the skeletal carbonate precipitating solution is reduced when the $\mathrm{pH}$ is lower, then light isotopes would be enriched in the calcifying fluid under less alkaline conditions, 15 because $\mathrm{B} / \mathrm{Ca}$ is positively correlated with $\delta^{18} \mathrm{O}$ and $\delta^{13} \mathrm{C}$ values (Fig. 4).

There are strict biological controls on the relative proportions of the three major inorganic carbon dioxide forms, aqueous carbon dioxide, bicarbonate $\left(\mathrm{HCO}_{3}^{-}\right)$, and carbonate ion $\left(\mathrm{CO}_{3}^{2-}\right)$, in the coral ECF. The different species of dissolved carbonate have different isotope fractionation factors and reaction rates; thus, the produced carbonates reflect the different proportions of these carbonate species present in the ECF during hydration, dehydration, and hydroxylation reactions (Usdowski and Hoefs, 1993; Zeebe, 2014). The $\mathrm{pH}$-dependent fractionation of ${ }^{18} \mathrm{O}$ and ${ }^{13} \mathrm{C}$ may be a result of both the relative proportions of carbonate species and kinetic isotope fractionation during hydration and hydroxylation (Adkins et al., 2003; Rollin-Bard et al., 2003). Recently,

experiments with cultured planktonic foraminifera have shown that $\delta^{18} \mathrm{O}$ and $\delta^{13} \mathrm{C}$ increase as $\mathrm{pH}$ decreases (Uchikawa and Zeebe, 2010). However, the isotope ratios of the calcitic corals in this study correlated positively with $\mathrm{B} / \mathrm{Ca}$, which is supposed to be an indicator of internal $\mathrm{pH}$ (Table 2).
BGD

12, 389-412, 2015

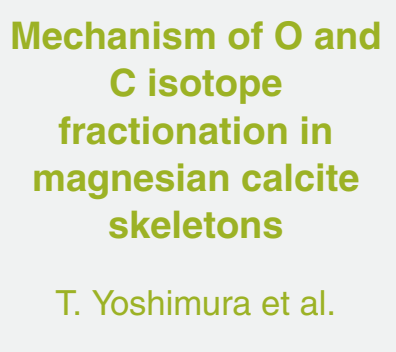

Title Page

Abstract

Introduction

Conclusions

Tables

References

Figures

14

$>1$

4

$\checkmark$

Back

Close

Full Screen / Esc

Printer-friendly Version

Interactive Discussion 
As previously mentioned in the Sect. 4.1, the large $\delta^{18} \mathrm{O}$ variation in aragonitic coral skeletons is caused by isotope disequilibrium during the rapid calcification (McConnaughey, 1989). According to Rollin-Bard et al. (2003), dissolved $\mathrm{CO}_{2}$ equilibrated with water at $\mathrm{pH} 9(\mathrm{pH} 7)$ requires a residence time of more than $12 \mathrm{~h}(1 \mathrm{~h})$, and $\mathrm{O}$ iso5 tope fractionation differences in reef-building corals are due to variations in the $\mathrm{pH}$ of the coral's calcifying fluid. However, because the calcification rates of calcitic corals are significantly lower by one or two orders of magnitude than those of reef-building corals, $\mathrm{CO}_{2}$ equilibration is probably established in the ECF of calcitic corals. Moreover, Zeebe et al. (1999b) have reported that carbon isotopic equilibration occurs on the order of 10 minutes. Therefore, the large $\delta^{18} \mathrm{O}$ and $\delta^{13} \mathrm{C}$ variations cannot be explained only by intercolony variations in the $\mathrm{pH}$ of the ECF and accompanying changes in the relative proportions of the dissolved carbonate species.

Because $\mathrm{O}$ and $\mathrm{C}$ isotope fractionation shows strong linear correlation in both aragonitic and calcitic corals that grow at intermediate and deep depths, the degree of biological control on isotope fractionation in aragonite and calcite must be similar. Adkins et al. (2003) proposed the existence of an interplay between two carbon pools, (1) dissolved carbon entering the calcification sites by diffusion through the calicoblastic cell wall $\left(\mathrm{CO}_{2}-\mathrm{ccw}\right)$ and (2) seawater DIC leak, during the mineralization process in the semi-isolated calcification space. At slower calcification rates, $\mathrm{CO}_{2}-\mathrm{ccw}$ is more influter (Adkins et al., 2003). As a result, a supply of dissolved carbon from the seawater DIC to the growing calcite crystals alters the isotopic composition of the calcifying fluid. According to the model of Adkins et al. (2003), lower pH at the calcification site leads to higher $\delta^{18} \mathrm{O}$ and $\delta^{13} \mathrm{C}$ values, and this model successfully explains the behavior of intra-skeleton isotope variations in six modern aragonitic deep-sea corals.

In contrast, our data on inter-colony variations suggest that a biologically induced gradient in the $\mathrm{pH}$ of the calcifying region results in positive $\mathrm{pH}$ dependence of the isotopic compositions. It is possible that a decline in internal $\mathrm{pH}$ in calcifying fluid causes $\left[\mathrm{CO}_{2}-\mathrm{CCW}\right]$ in the ECF to increase; thus, the relative contribution of isotopically heavy
BGD

12, 389-412, 2015

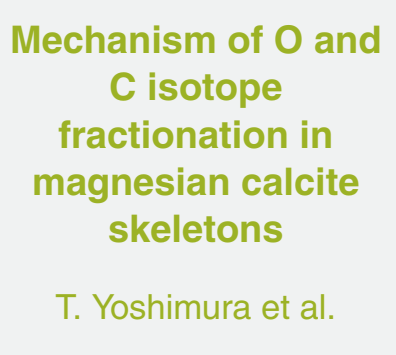

Title Page

Abstract

Introduction

Conclusions

Tables

References

Figures

14

$\rightarrow 1$

4

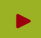

Back

Close

Full Screen / Esc

Printer-friendly Version

Interactive Discussion 
$\mathrm{CO}_{2}$ from seawater passively diffusing across the cell membrane, or that through the skeleton and pericellular channels, decreases. These observed changes in oxygen and carbon isotope fractionation and boron element partitioning at the site of calcification provide an insight into the calcification responses of corals to $\mathrm{CO}_{2}$-induced ocean acid5 ification. Corals regularly experience fluctuations in multiple environmental and physiological parameters that affect variations in calcifying fluid $\mathrm{pH}$ and act to disrupt $\mathrm{pH}$ regulation. Recently, boron isotope proxy and direct measurement of calcifying fluid $\mathrm{pH}$ both showed greater $\mathrm{pH}$ offsets between the calcifying fluid and seawater with ocean acidification (McCulloch et al., 2012b; Anagnostou et al., 2012; Venn et al., 2013). Al10 though seawater acidification definitely causes significant declines in intra-cellular $\mathrm{pH}$ in coral calcifying cells and extracellular $\mathrm{pH}$ in the calcifying fluid at the tissue-skeleton interface (Ries, 2011a; Venn et al., 2013), corals exert stronger physiological control on their calcifying fluid $\mathrm{pH}$ by the ability to up-regulate $\mathrm{pH}$ at the site of calcification (McCulloch et al., 2012b; Venn et al., 2013). These results are consistent with the observed 15 behavior of skeletal $\mathrm{O}$ and $\mathrm{C}$ isotopic compositions of calcitic coral, in which declines in calcifying fluid $\mathrm{pH}$ were accompanied by the higher $\left[\mathrm{CO}_{2}-\mathrm{ccw}\right]$ contributions, suggesting that the potential role of biological alkalinity pumping becomes more favorable with a decrease in calcifying fluid $\mathrm{pH}$.

Skeletal growth in coral occurs in the extracellular calcifying space, which allows 20 the coral to control its internal chemistry. Note that the declines in calcifying fluid $\mathrm{pH}$ are small relative to the changes in external seawater $\mathrm{pH}$, as observed by biological and geochemical approaches (McCulloch et al., 2012b; Anagnostou et al., 2012; Venn et al., 2013). The zooxanthellae-bearing, reef-building corals can sustain calcification over a wide range of acidified seawater conditions owing to photosynthetically supplied energy (McCulloch et al., 2012b). Due to an absence of zooxanthellae, fewer energy resources may be a significant physiological limitation of azooxanthellae corals, leading to slower growth rates (McCulloch et al., 2012a). The energy required to manipulate calcification systems is likely to be a critical factor, and calcification processes may be dependent on the rate of carbon supply needed to build organic templates, as well as
BGD

12, 389-412, 2015

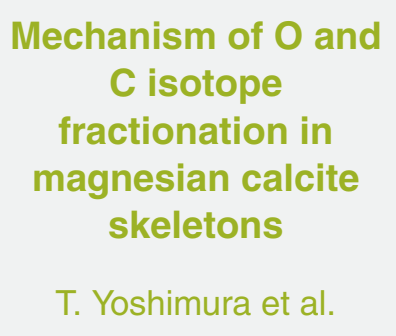

Title Page

Abstract Introduction

Conclusions

Tables

References

Figures

14

$>$ I

$\triangleleft$

$\checkmark$

Back

Close

Full Screen / Esc

Printer-friendly Version

Interactive Discussion 
to manipulate DIC sources of the calcification fluids. Substantial interspecimen differences were observed in the $\mathrm{B} / \mathrm{Ca}$ ratios at each habitat depth; these ratios are possible proxies for $\mathrm{pH}$ in seawater or ECF. Thus, the $\mathrm{B} / \mathrm{Ca}$ ratios in calcitic corals appear to reflect ECF conditions rather than ambient seawater, and any environmental effects 5 were likely overridden by biological factors. In the present case of calcitic Octocorallia corals, physiological limitations such as food supply, health status, and development stages of the corals play crucial roles in regulating their calcifying fluid composition and are essential for enzyme-driven reactions such as Ca-ATPase, carbonic anhydrases. The energy requirement on the resilience to the effects of ocean acidification may in10 dependently be affected by changes in the extracellular $\mathrm{pH}$ gradient between seawater and the calcification site. One proton-pumping physicochemical model of the energetic demands of maintaining coral calcification at $\mathrm{CO}_{2}$-induced ocean acidification is not necessarily associated with the additional energy cost (Ries, 2011b). However, corals have the ability to buffer external changes in seawater inorganic carbon systems by 15 regulating their pH (Ries, 2011b; McCulloch et al., 2012a, b; Venn et al., 2013) and also the DIC sources at the site of calcification across a membrane. Given that the present isotopic data also suggest an even stronger biological control on the inorganic carbon system of the ECF under reduced calcifying fluid $\mathrm{pH}$, the biological manipulation on sources of DIC in response to acidification favors skeletal growth; thus, calcifying fluid $\mathrm{pH}$ is less affected by ambient seawater. Although still qualitative, clarification of the mechanisms of $\mathrm{O}$ and $\mathrm{C}$ isotope disequilibrium in Octocorallia coral skeletons, composed of more soluble $\mathrm{CaCO}_{3}$ polymorphs of high-Mg calcite would provide insight into the manner in which the ambient seawater chemistry impacts the DIC chemistry of the calcifying fluid. We expect this knowledge to be useful in environmental and biological

Acknowledgements. We express our appreciation to Naohiko Ohkouchi and Saburo Sakai of JAMSTEC for valuable advice; to Yumiko Yoshinaga and Mizuho Sato of AIST for laboratory assistance; to Hisaichi Kawaguchi, Takuji Osato, Noriyoshi Yoshimoto, Yoshihiko Niiya, Hidekazu Muraoka, and to the crew of the R/V Hakurei-maru No. 2 for providing the deep-sea coral spec-

BGD

12, 389-412, 2015

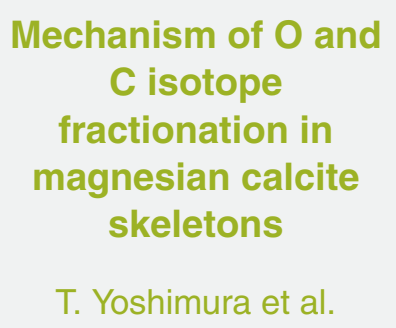

Title Page

Abstract Introduction

Conclusions

Tables

References

Figures

14

$>$ I

4

$\checkmark$

Back

Close

Full Screen / Esc

Printer-friendly Version

Interactive Discussion 
imens. This work was performed with the support of Ministry of the Environment, the Environment Research and Technology Development Fund (2A-1203. Experimental study of multiple impacts of global warming and ocean acidification on marine species).

\section{References}

5 Adkins, J. F., Cheng, H., Boyle, E. A., Druffel, E. R., and Edwards, R. L.: Deep-sea coral evidence for rapid change in ventilation of the deep North Atlantic 15,400 years ago, Science, 280, 725-728, 1998.

Adkins, J. F., Boyle, E. A., Curry, W. B., and Lutringer, A.: Stable isotopes in deep-sea corals and a new mechanism for "vital effects", Geochim. Cosmochim. Ac., 67, 1129-1143, 2003.

Allen, K. A. and Hönisch, B.: The planktic foraminiferal B/Ca proxy for seawater carbonate chemistry: a critical evaluation, Earth Planet. Sc. Lett., 345, 203-211, 2012.

Anagnostou, E., Huang, K. F., You, C. F., Sikes, E. L., and Sherrell, R. M.: Evaluation of boron isotope ratio as a pH proxy in the deep sea coral Desmophyllum dianthus: evidence of physiological pH adjustment, Earth Planet. Sc. Lett., 349, 251-260, 2012.

Chacko, T. and Deines, P.: Theoretical calculation of oxygen isotope fractionation factors in carbonate systems, Geochim. Cosmochim. Ac., 72, 3642-3660, 2008.

Cohen, A. L. and McConnaughey, T. A.: Geochemical perspectives on coral mineralization, Rev. Mineral. Geochem., 54, 151-187, 2003.

Eltgroth, S. F., Adkins, J. F., Robinson, L. F., Southon, J., and Kashgarian, M.: A deepsea coral record of North Atlantic radiocarbon through the Younger Dryas: evidence for intermediate water/deepwater reorganization, Paleoceanography, 21, PA4207, doi:10.1029/2005PA001192, 2006.

Foster, G. L.: Seawater $\mathrm{pH}, p \mathrm{CO}_{2}$ and $\left[\mathrm{CO}_{3}^{2-}\right]$ variations in the Caribbean Sea over the last 130 kyr: a boron isotope and B/Ca study of planktic foraminifera, Earth Planet. Sc. Lett., 271, 254-266, 2008.

Griffin, S. and Druffel, E. R.: Sources of carbon to deep sea corals, Radiocarbon, 31, 533-543, 1989.

Heikoop, J. M., Hickmott, D. D., Risk, M. J., Shearer, C. K., and Atudorei, V.: Potential climate signals from the deep-sea gorgonian coral Primnoa resedaeformis, Hydrobiologia, 471, 117-
BGD

$12,389-412,2015$

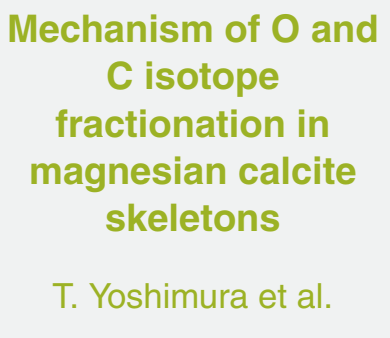

Title Page

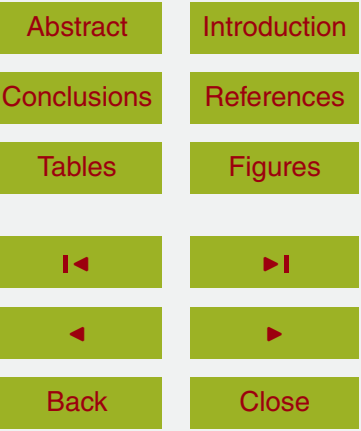

Full Screen / Esc

Printer-friendly Version

Interactive Discussion 
Hill, T. M., Spero, H. J., Guilderson, T., LaVigne, M., Clague, D., Macalello, S., and Jang, N.: Temperature and vital effect controls on bamboo coral (Isididae) isotope geochemistry: a test of the "lines method", Geochem. Geophy. Geosy., 12, Q04008, doi:10.1029/2010GC003443, 2011.

5 IPCC: Summary for policymakers, in: Climate Change 2014: Impacts, Adaptation, and Vulnerability. Part A: Global and Sectoral Aspects, Contribution of Working Group II to the Fifth Assessment Report of the Intergovernmental Panel on Climate Change, Cambridge University Press, Cambridge, UK and New York, NY, USA, 1-32, 2014.

Iwasaki, N. (ed.): A Biohistory of Precious Corals: Scientific, Cultural and Historical Perspectives, Tokai University Press, Japan, 2010.

Jimenez-Lopez, C., Romanek, C. S., Huertas, F. J., Ohmoto, H., and Caballero, E.: Oxygen isotope fractionation in synthetic magnesian calcite, Geochim. Cosmochim. Ac., 68, 33673377, 2004.

Jimenez-Lopez, C., Romanek, C. S., and Caballero, E.: Carbon isotope fractionation in syn15 thetic magnesian calcite, Geochim. Cosmochim. Ac., 70, 1163-1171, 2006.

Kakihana, H., Kotaka, M., Satoh, S., Nomura, M., and Okamoto, M.: Fundamental studies on the ion-exchange separation of boron isotopes, Chem. Soc. Jpn. B, 50, 158-163, 1977.

Key, R. M., Kozyr, A., Sabine, C. L., Lee, K., Wanninkhof, R., Bullister, J. L., Feely, R. A., Millero, F. J., Mordy, C., and Peng, T.-H.: A global ocean carbon climatology: results from Global Data Analysis Project (GLODAP), Global Biogeochem. Cy., 18, GB4031, doi:10.1029/2004GB002247, 2004.

Kimball, J. B., Dunbar, R. B., and Guilderson, T. P.: Oxygen and carbon isotope fractionation in calcitic deep-sea corals: implications for paleotemperature reconstruction, Chem. Geol., 381, 223-233, 2014.

LaVigne, M., Hill, T. M., Spero, H. J., and Guilderson, T. P.: Bamboo coral Ba/Ca: calibration of a new deep ocean refractory nutrient proxy, Earth Planet. Sc. Lett., 312, 506-515, 2011.

Levitus, S. and Boyer, T. P.: World Ocean Atlas 1994, vol. 4: Temperature Number 4, 1994.

Lewis, E. and Wallace, D. W. R.: CO2SYS - Program Developed for the $\mathrm{CO}_{2}$ System Calculations, Carbon Dioxide Inf. Anal. Center; Report, ORNL/CDIAC-105, 1998.

30 Mavromatis, V., Schmidt, M., Botz, R., Comas-Bru, L., and Oelkers, E. H.: Experimental quantification of the effect of $\mathrm{Mg}$ on calcite-aqueous fluid oxygen isotope fractionation, Chem. Geol., 310-311, 97-105, 2012.
BGD

12, 389-412, 2015

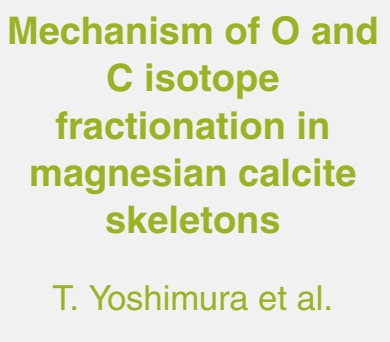

Title Page

Abstract

Introduction

Conclusions

Tables

References

Figures

14

$\rightarrow 1$

4

-

Back

Close

Full Screen / Esc

Printer-friendly Version

Interactive Discussion 
McConnaughey, T.: ${ }^{13} \mathrm{C}$ and ${ }^{18} \mathrm{O}$ isotopic disequilibrium in biological carbonate: II. In vitro simulation of kinetic isotope effects, Geochim. Cosmochim. Ac., 53, 163-171, 1989.

McConnaughey, T. A., Burdett, J., Whelan, J. F., and Charles, K. P.: Carbon isotope in biological carbonates: respiration and photosynthesis, Geochim. Cosmochim. Ac., 61, 611-622, 1997.

5 McCulloch, M., Trotter, J., Montagna, P., Falter, J., Dunbar, R., Freiwald, A., Försterra, G., Correa, M. L., Maier, C., Rüggeberg, A., and Taviani, M.: Resilience of cold-water scleractinian corals to ocean acidification: boron isotopic systematics of $\mathrm{pH}$ and saturation state up-regulation, Geochim. Cosmochim. Ac., 87, 21-34, 2012a.

McCulloch, M., Falter, J., Trotter, J., and Montagna, P.: Coral resilience to ocean acidification 10 and global warming through $\mathrm{pH}$ up-regulation, Nature Climate Change, 2, 623-627, 2012b.

Montagna, P., McCulloch, M., Taviani, M., Mazzoli, C., and Vendrell, B.: Phosphorus in coldwater corals as a proxy for seawater nutrient chemistry, Science, 312, 1788-1791, 2006.

Okai, T., Suzuki, A., Terashima, S., Inoue, M., Nohara, M., Kawahata, H., and Imai, N.: Collaborative analysis of GSJ/AIST geochemical reference materials JCp-1 (Coral) and JCt-1 (Giant 15 Clam), Geochemistry, 38, 281-286, 2004 (in Japanese).

Omata, T., Suzuki, A., Sato, T., Minoshima, K., Nomaru, E., Murakami, A., Murayama, S., Kawahata, H., and Maruyama, T.: Effect of photosynthetic light dosage on carbon isotope composition in the coral skeleton: long-term culture of Porites spp., J. Geophys. Res., 113, G02014, doi:10.1029/2007JG000431, 2008.

Ries, J. B.: A physicochemical framework for interpreting the biological calcification response to $\mathrm{CO}_{2}$-induced ocean acidification, J. Exp. Mar. Biol. Ecol., 403, 54-64, 2011 a.

Ries, J. B.: Skeletal mineralogy in a high- $\mathrm{CO}_{2}$ world, Geochim. Cosmochim. Ac., 75, 40534064, 2011b.

Ries, J. B., Cohen, A. L., and McCorkle, D. C.: Marine calcifiers exhibit mixed responses to $\mathrm{CO}_{2}$-induced ocean acidification, Geology, 37, 1131-1134, 2009.

Rollion-Bard, C., Chaussidon, M., and France-Lanord, C.: pH control on oxygen isotopic composition of symbiotic corals, Earth Planet. Sc. Lett., 215, 275-288, 2003.

Romanek, C., Grossman, E., and Morse, J.: Carbon isotopic fractionation in synthetic calcite, effects of temperature and precipitation rate, Geochim. Cosmochim. Ac., 56, 419-430, 1992. composition of calcite: evidence from inorganic calcite precipitation experiments, Geochim. Cosmochim. Ac., 64, 1551-1555, 2000.

\section{Mechanism of $\mathrm{O}$ and C isotope \\ fractionation in \\ magnesian calcite \\ skeletons \\ T. Yoshimura et al.}

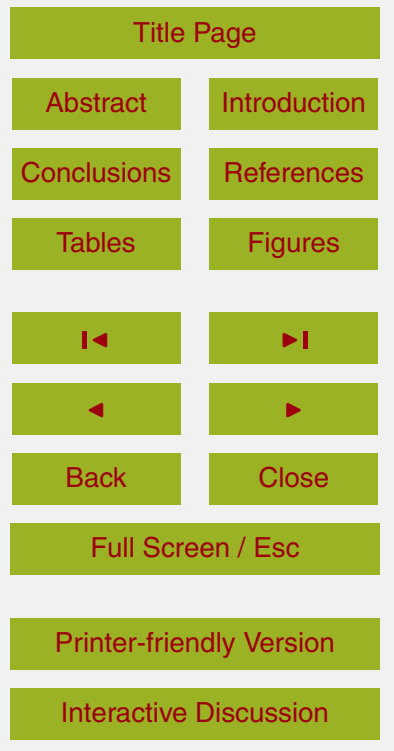


Schauble, E. A., Ghosh, P., and Eiler, J. M.: Preferential formation of ${ }^{13} \mathrm{C}-{ }^{18} \mathrm{O}$ bonds in carbonate minerals, estimated using first-principles lattice dynamics, Geochim. Cosmochim. Ac., 70, 2510-2529, 2006.

Sherwood, O. A., Heikoop, J. M., Scott, D. B., Risk, M. J., Guilderson, T. P., and McKinney, R. A.: Stable isotopic composition of deep-sea gorgonian corals Primnoa spp.: a new archive of surface processes, Mar. Ecol.-Prog. Ser., 301, 135-148, 2005.

Smith, J. E., Risk, M. J., Schwarcz, H. P., and McConnaughey, T. A.: Rapid climate change in the North Atlantic during the Younger Dryas recorded by deep-sea corals, Nature, 386, 818-820, 1997.

10 Smith, J. E., Schwarcz, H. P., Risk, M. J., McConnaughey, T. A., and Keller, N.: Paleotemperatures from deep-sea corals: overcoming "vital effects", Palaios, 15, 25-32, 2000.

Spero, H. J., Bijma, J., Lea, D. W., and Bemis, B. E.: Effect of seawater carbonate concentration on foraminiferal carbon and oxygen isotopes, Nature, 390, 497-500, 1997.

Suzuki, A., Hibino, K., Iwase, A., and Kawahata, H.: Intercolony variability of skeletal oxygen and carbon isotope signatures of cultured Porites corals: temperature-controlled experiments, Geochim. Cosmochim. Ac., 69, 4453-4462, 2005.

Tarutani, T., Clayton, R. N., and Mayeda, T. K.: The effect of polymorphism and magnesium substitution on oxygen isotope fractionation between calcium carbonate and water, Geochim. Cosmochim. Ac., 33, 987-996, 1969.

Tripati, A. K., Roberts, C. D., Eagle, R. A., and Li, G.: A 20 million year record of planktic foraminiferal $\mathrm{B} / \mathrm{Ca}$ ratios: systematics and uncertainties in $p \mathrm{CO}_{2}$ reconstructions, Geochim. Cosmochim. Ac., 75, 2582-2610, 2011.

Uchikawa, J. and Zeebe, R. E.: Examining possible effects of seawater $\mathrm{pH}$ decline on foraminiferal stable isotopes during the Paleocene-Eocene Thermal Maximum, Paleoceanography, 25, PA2216, doi:10.1029/2009PA001864, 2010.

Urey, H.: The thermodynamic properties of isotopic substances, J. Chem. Soc. London, 562$581,1947$.

Usdowski, E. and Hoefs, J.: Oxygen isotope exchange between carbonic acid, bicarbonate, carbonate, and water: a re-examination of the data of McCrea (1950) and an expression Geochim. Cosmochim. Ac., 57, 3815-3818, 1993.

BGD

12, 389-412, 2015

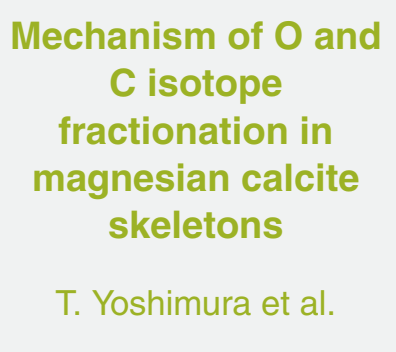

Title Page

Abstract

Introduction

Conclusions

Tables

References

Figures

14

$>1$

$\triangleleft$

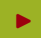

Back

Close

Full Screen / Esc

Printer-friendly Version

Interactive Discussion 
van de Flierdt, T., Robinson, L. F., Adkins, J. F., Hemming, S. R., and Goldstein, S. L.: Temporal stability of the neodymium isotope signature of the Holocene to glacial North Atlantic, Paleoceanography, 21, PA4102, doi:10.1029/2006PA001294, 2006.

Venn, A. A., Tambutté, E., Holcomb, M., Laurent, J., Allemand, D., and Tambutté, S.: Impact of 5 seawater acidification on $\mathrm{pH}$ at the tissue-skeleton interface and calcification in reef corals, P. Natl. Acad. Sci. USA, 110, 1634-1639, 2013.

Yoshimura, T., Tanimizu, M., Inoue, M., Suzuki, A., Iwasaki, N., and Kawahata, H.: Mg isotope fractionation in biogenic carbonates of deep-sea coral, benthic foraminifera, and hermatypic coral, Anal. Bioanal. Chem., 401, 2755-2769, 2011.

$10 \mathrm{Yu}, \mathrm{J}$., Elderfield, H., and Hönisch, B.: B/Ca in planktonic foraminifera as a proxy for surface seawater $\mathrm{pH}$, Paleoceanography, 22, PA22ccq02, doi:10.1029/2006PA001347, 2007.

Zeebe, R. E.: Kinetic fractionation of carbon and oxygen isotopes during hydration of carbon dioxide, Geochim. Cosmochim. Ac., 139, 540-552, 2014.

Zeebe, R. E., Bijma, J., and Wolf-Gladrow, D. A.: A diffusion-reaction model of carbon isotope 15 fractionation in foraminifera, Mar. Chem., 64, 199-227, 1999a.

Zeebe, R. E., Wolf-Gladrow, D. A., and Jansen, H.: On the time required to establish chemical and isotopic equilibrium in the carbon dioxide system in seawater, Mar. Chem., 65, 135-153, 1999b.

Yoshimura, T., Suzuki, A., and Iwasaki, N.: Ba, B, and $U$ element partitioning in magnesian calcite skeletons of Octocorallia corals, Biogeosciences Discuss., 12, 413-444, doi:10.5194/bgd-12-413-2015, 2015.

Title Page

Abstract

Conclusions

Tables

14

4

Back

Full Screen / Esc

Printer-friendly Version

Interactive Discussion 
Table 1. Sampling locations, water depth and temperature, stable oxygen and carbon isotope ratios of the coral samples. The $\Delta^{18} \mathrm{O}$ and $\Delta^{13} \mathrm{C}$ were calculated by using isotope fractionation factors for inorganic magnesian calcite (Mavromatis et al., 2012; Jimenez-Lopez, 2006).

\begin{tabular}{|c|c|c|c|c|c|c|c|c|c|c|}
\hline Sample ID & Taxa & $\begin{array}{l}\text { Vernacular } \\
\text { name }\end{array}$ & $\begin{array}{l}\text { Latitude/ } \\
\text { Longitude }\end{array}$ & $\begin{array}{c}\text { Depth } \\
\text { m }\end{array}$ & $\begin{array}{c}\text { Temp. } \\
{ }^{\circ} \mathrm{C}\end{array}$ & $\begin{array}{c}\delta^{18} \mathrm{O} \\
\% \circ \text { VPDB }\end{array}$ & $\begin{array}{c}\delta^{18} \mathrm{O}_{\text {coral }} \\
\delta^{18} \mathrm{O}_{\text {calc }}\end{array}$ & $\begin{array}{c}\delta^{13} \mathrm{C} \\
\% \circ \text { VPDB }\end{array}$ & $\begin{array}{c}\delta^{13} \mathrm{C}_{\text {coral }}- \\
\delta^{13} \mathrm{C}_{\text {calc }}\end{array}$ & $\begin{array}{c}\mathrm{Mg} / \mathrm{Ca} \\
\mathrm{mmol} \mathrm{mol}^{-1}\end{array}$ \\
\hline DPC-01 & Corallium konojoi & White coral & $32^{\circ} \mathrm{N} 134^{\circ} \mathrm{E}$ & 100 & 19.5 & -1.80 & -2.20 & -3.63 & -5.38 & 116.56 \\
\hline DPC-12 & Paracorallium & Japanese & $32^{\circ} \mathrm{N} 134^{\circ} \mathrm{E}$ & 100 & 19.5 & -1.15 & -1.53 & 0.00 & -1.75 & 116.71 \\
\hline DPC-K1 & japonicum & red coral & $25^{\circ} \mathrm{N} 126^{\circ} \mathrm{E}$ & $200-300$ & 18.0 & -0.73 & -1.83 & -0.54 & -2.00 & 137.40 \\
\hline DPC-0812 & Corallium elatius & Pink coral & $25^{\circ} \mathrm{N} 126^{\circ} \mathrm{E}$ & $200-300$ & 18.0 & -1.12 & -1.94 & -0.95 & -2.41 & 121.52 \\
\hline DPC-14 & Keratoisis sp. & Bamboo coral & $27^{\circ} \mathrm{N} 142^{\circ} \mathrm{E}$ & 700 & 7.0 & 0.74 & -2.58 & -2.10 & -2.97 & 90.93 \\
\hline DPC-K4 & Corallium sp. & Deep-sea coral & $32^{\circ} \mathrm{N} 132^{\circ} \mathrm{E}$ & 100 & 19.5 & -1.61 & -2.22 & -5.07 & -6.81 & 130.94 \\
\hline DPC-K3 & Corallium sp. & Deep-sea coral & $27^{\circ} \mathrm{N} 142^{\circ} \mathrm{E}$ & 700 & 6.5 & 0.24 & -3.15 & -4.95 & -5.82 & 86.59 \\
\hline DPC-K5 & Corallium sp. & Deep-sea coral & $28^{\circ} \mathrm{N} 177^{\circ} \mathrm{E}$ & 1000 & 3.5 & 0.20 & -3.89 & -6.12 & -6.70 & 78.40 \\
\hline DPC-V1 & Corallium sp. & Deep-sea coral & $9^{\circ} \mathrm{N} 109^{\circ} \mathrm{E}$ & $200-400$ & $10-15$ & -2.38 & -4.66 & -5.95 & -7.34 & 113.58 \\
\hline DPC-V4 & Corallium sp. & Deep-sea coral & $9^{\circ} \mathrm{N} 109^{\circ} \mathrm{E}$ & $200-400$ & $10-15$ & -1.72 & -4.06 & -4.32 & -5.71 & 117.69 \\
\hline DPC-951 & Corallium sp. & Deep-sea coral & $35^{\circ} \mathrm{N} 139^{\circ} \mathrm{E}$ & 105 & 17.5 & -1.09 & -2.10 & -4.12 & -5.85 & 123.13 \\
\hline
\end{tabular}

Mechanism of $\mathrm{O}$ and

C isotope

fractionation in

magnesian calcite

skeletons

T. Yoshimura et al.

\section{Title Page}

Abstract

Introduction

Conclusions References

Tables

Figures

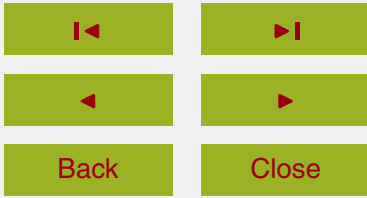

Full Screen / Esc

Printer-friendly Version

Interactive Discussion 
Table 2. Correlation coefficients $(r)$ and $p$ values obtained by regressing $\delta^{18} \mathrm{O}$ and $\delta^{13} \mathrm{C}$ against various parameters. The inorganic carbon data were calculated from alkalinity and total dissolved inorganic carbon data made available by the Global Ocean Data Analysis Project.

\begin{tabular}{lccccccccc}
\hline & Temp. & $\mathrm{pH}$ & $p \mathrm{CO}_{2}$ & $\mathrm{HCO}_{3}^{-}$ & $\mathrm{CO}_{3}^{2-}$ & $\mathrm{HCO}_{3}^{-} / \mathrm{CO}_{3}^{2-}$ & $\mathrm{B} / \mathrm{Ca}$ & $\mathrm{U} / \mathrm{Ca}$ \\
\hline$\delta^{18} \mathrm{O}_{\text {coral }}-\delta^{18} \mathrm{O}_{\text {calc }}$ & $r$ & 0.652 & 0.727 & -0.696 & -0.750 & 0.733 & -0.620 & 0.478 & 0.342 \\
& $p$ & 0.0001 & 0.0059 & 0.0012 & 0.0648 & 0.0000 & 0.0030 & 0.0041 & 0.0001 \\
\hline$\delta^{13} \mathrm{C}_{\text {coral }}-\delta^{13} \mathrm{C}_{\text {calc }}$ & $r$ & 0.318 & 0.332 & -0.372 & -0.325 & 0.304 & -0.370 & 0.678 & -0.133 \\
& $p$ & 0.0042 & 0.2225 & 0.0045 & 0.8117 & 0.0031 & 0.0069 & 0.0007 & 0.0014 \\
\hline
\end{tabular}

\section{BGD}

$12,389-412,2015$

Mechanism of $\mathrm{O}$ and

C isotope

fractionation in

magnesian calcite

skeletons

T. Yoshimura et al.

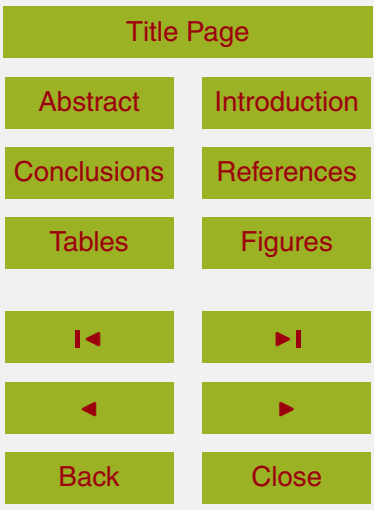

Full Screen / Esc

Printer-friendly Version

Interactive Discussion 


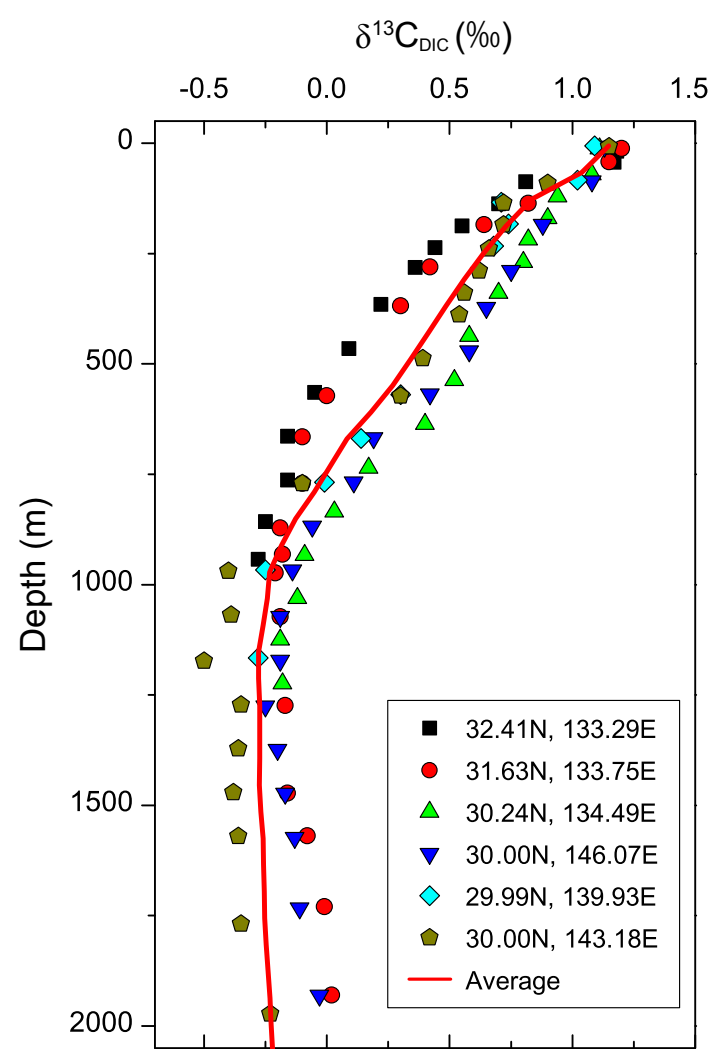

Mechanism of $\mathrm{O}$ and

C isotope

fractionation in

magnesian calcite

skeletons

T. Yoshimura et al.

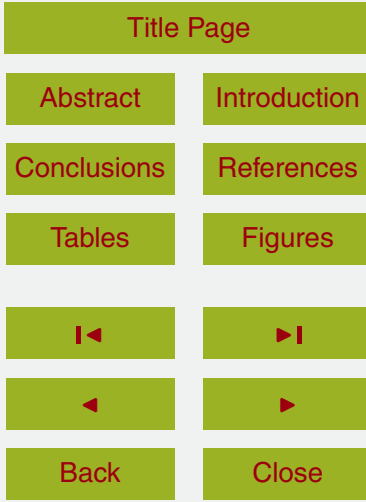

Figure 1. Comparison of $\delta^{13} \mathrm{C}_{\mathrm{DIC}}$-depth relationships among North Pacific sites. We selected published data collected at points close to the sampling localities of the corals analyzed in this study. The $\delta^{13} \mathrm{C}$ carbon data were collected along sections P02, P09, and P10 in the Pacific Ocean distributed by the Global Ocean Data Analysis Project. The $\delta^{13} \mathrm{C}_{\mathrm{DIC}}$ values used to evaluate proxies were estimated from the curve obtained by averaging data from the Northwest Pacific sites.

\section{Full Screen / Esc}

Printer-friendly Version

Interactive Discussion 

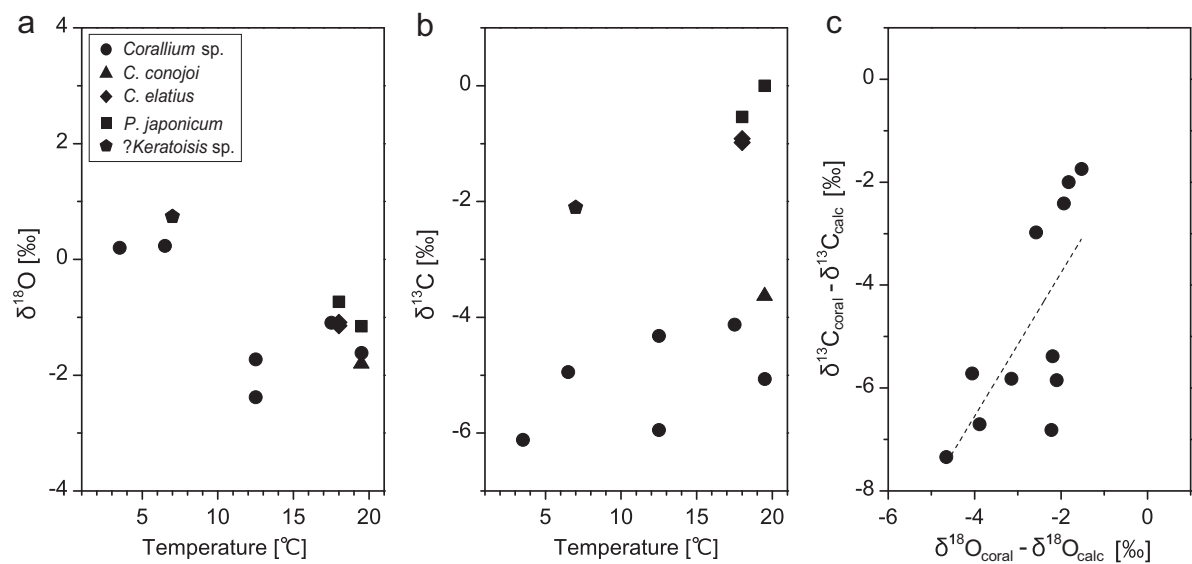

Figure 2. (a) Scatter plots of $\delta^{18} \mathrm{O}$ and (b) $\delta^{13} \mathrm{C}$ vs. temperature for a suite of Octocorallia deepsea corals collected from a large range of depths. (c) Scatter plot of $\Delta^{13} \mathrm{C}\left(\delta^{13} \mathrm{C}_{\text {coral }}-\delta^{13} \mathrm{C}_{\text {calc }}\right)$ vs. $\Delta^{18} \mathrm{O}\left(\delta^{18} \mathrm{O}_{\text {coral }}-\delta^{18} \mathrm{O}_{\text {calc }}\right)$ for Octocorallia corals. $\delta^{18} \mathrm{O}_{\text {calc }}$ and $\delta^{13} \mathrm{C}_{\text {calc }}$ values were calculated by using empirically determined fractionation factors for inorganic calcite (Mavromatis et al., 2012; Jimenez-Lopez, 2006); and $\delta^{18} \mathrm{O}_{\text {coral }}$ and $\delta^{13} \mathrm{C}_{\text {coral }}$ values were calculated from the water temperature and $\mathrm{Mg} / \mathrm{Ca}$ ratios of the corals (Yoshimura et al., 2011) using the equations of Mavromatis et al. (2012) and Jimenez-Lopez (2006), respectively.

Mechanism of $\mathrm{O}$ and

C isotope

fractionation in

magnesian calcite

skeletons

T. Yoshimura et al.

Title Page

Abstract

Introduction

Conclusions

References

Tables

Figures

14

$\rightarrow 1$

4

Back

Close

Full Screen / Esc

Printer-friendly Version

Interactive Discussion 


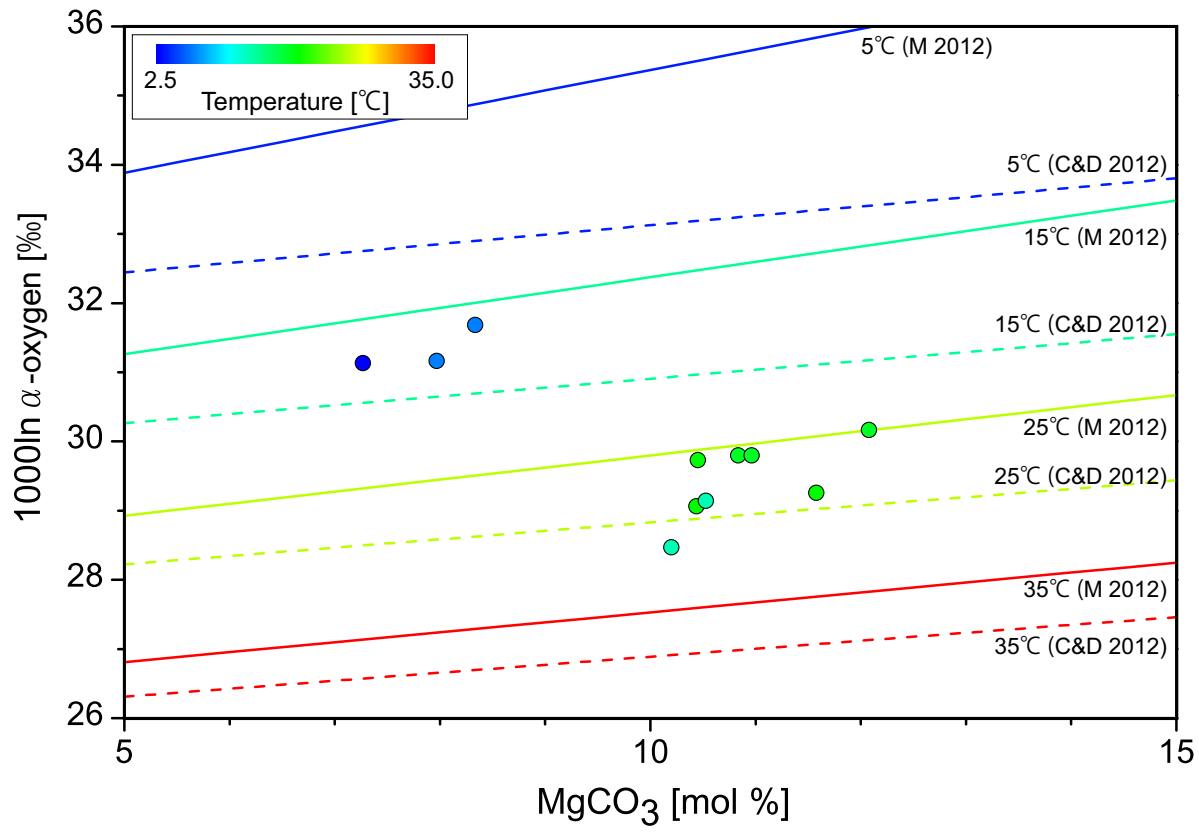

Figure 3. Relationships between oxygen isotope fractionation factor $(\alpha)$ and $\mathrm{Mg} / \mathrm{Ca}$ (shown as $\left.\left[\mathrm{MgCO}_{3}\right]\right)$ at different temperatures, calculated by using $\alpha$ values determined empirically from inorganically precipitated high-Mg calcite (solid lines: Mavromatis et al., 2012) and theoretically (dashed lines: Chacko and Deines, 2008). The measured $\delta^{18} \mathrm{O}$ and $\mathrm{Mg} / \mathrm{Ca}$ ratios of the corals (blue and green circles) are also plotted. The colors of the lines and symbols indicate the formation temperature of the calcite.

\section{BGD}

$12,389-412,2015$

\section{Mechanism of $\mathrm{O}$ and \\ C isotope \\ fractionation in \\ magnesian calcite \\ skeletons \\ T. Yoshimura et al.}

Title Page

Abstract

Introduction

Conclusions

References

Tables

Figures

14

\section{$\rightarrow 1$}

4

Back

Close

\section{Full Screen / Esc}

Printer-friendly Version

Interactive Discussion 

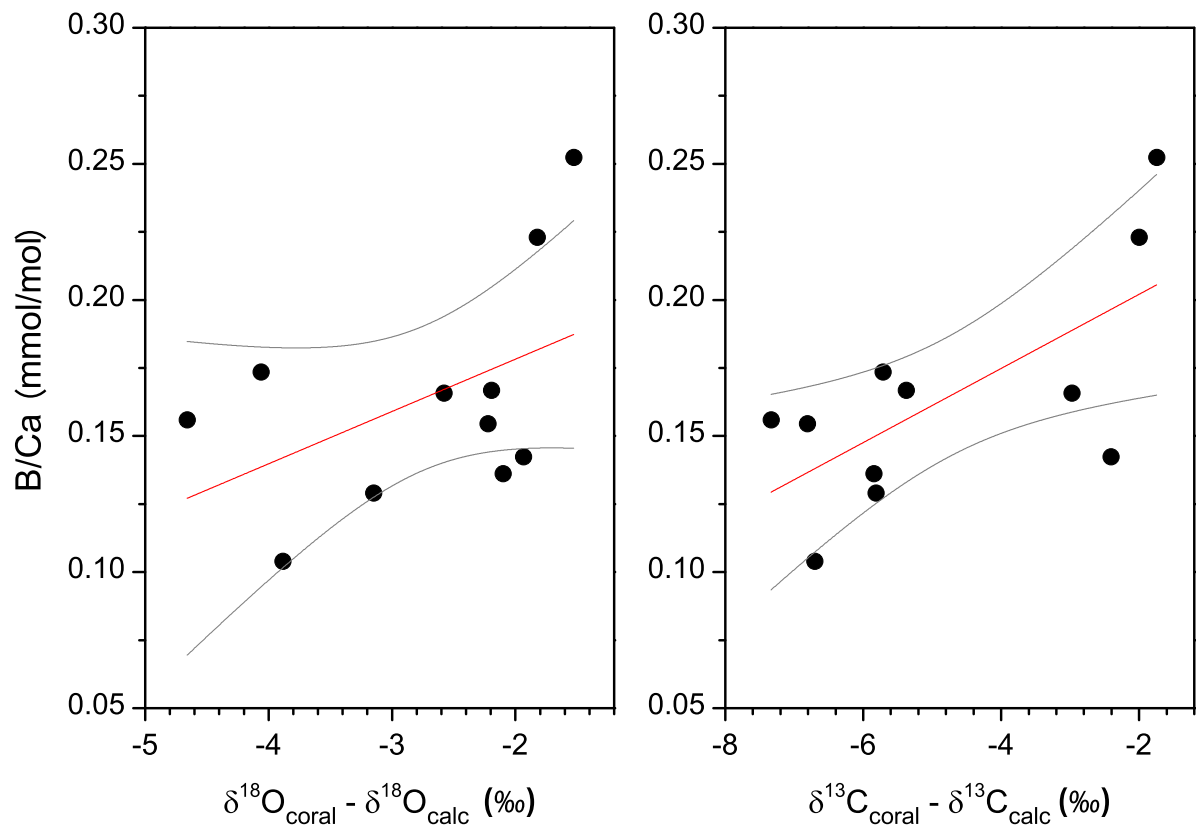

BGD

12, 389-412, 2015

Mechanism of $\mathrm{O}$ and

C isotope

fractionation in

magnesian calcite

skeletons

T. Yoshimura et al.

Title Page

Abstract

Introduction

Conclusions

References

Tables

Figures

14

$\rightarrow 1$

Figure 4. Scatter plots of measured $\mathrm{B} / \mathrm{Ca}$ ratios of high-Mg calcite skeletons of Octocorallia corals against the difference values $\left(\delta^{18} \mathrm{O}_{\text {coral }}-\delta^{18} \mathrm{O}_{\text {calc }}\right.$ and $\left.\delta^{13} \mathrm{C}_{\text {coral }}-\delta^{13} \mathrm{C}_{\text {calc }}\right)$ estimated by examining the effect of both temperature and $\mathrm{Mg}$ content on calcite-fluid isotope fractionation in synthetic magnesian calcite (Jimenez-Lopez et al., 2006; Mavromatis et al., 2012). The correlation coefficients $(r)$ and $p$ values obtained by regressing parameters were listed in Table 2 . The regression lines are shown with $95 \%$ confidence bounds.

Full Screen / Esc

Printer-friendly Version

Interactive Discussion 